\title{
EFFECTIVENESS OF BACILLUS SPP. PRESS ON BLUE GREEN ALGAE (BGA) CAUSING OFF-FLAVOR IN CATFISH CULTIVATION
}

\author{
Moh. Zharfan Abd. Djamila,*, Djumbuh Rukmono ${ }^{\mathrm{b}}$, Heny Budi Utari ${ }^{\mathrm{c}}$ \\ a,b,c Politeknik Ahli Usaha Perikanan, Jakarta Selatan, Indonesia \\ *Koresponden penulis: mohzharfan@yahoo.com
}

\begin{abstract}
Abstrak
Permasalahan yang selalu menjadi keresahan para pelaku usaha budidaya ikan patin yaitu adanya indikasi bau lumpur/tanah/muddy taste atau yang lebih dikenal dengan istilah off-flavours. Off-flavours tersebut diidentifikasi berasal darisenyawa kimia geosmin (GSM) dan 2-Methyl Iso-borneol (MIB) yang diproduksi oleh Cyanophyceae (Blue Green Algae atau BGA) dan Actinomycetes. Senyawa bau tanah ini larut dalam air, masuk kedalam tubuh ikan melalui insang dan diteruskan pada jaringan lemak ikan sehingga lama kelamaan daging ikan terasa bau lumpur/tanah/apak. Probiotik merupakan salah satu upaya untuk menurunkan senyawa penyebab off-flavours. Penggunaan probiotik yang mengandung Bacillus spp. pada pakan dapat mendegradasi bahan organik melalui bioremediasi organ pencernaan ikan dan lingkungan budidaya untuk meminimalisir akumulasi bahan organik. Berkurangnya bahan organik diperairan dalam bentuk total organik berdampak pada persentase BGA penyebab bau tanah didalam perairan terutama untuk jenis Oscillatoria Sp. Dalam penelitian ini kami menggunakan Bacillus spp. dengan perlakukan $10 \mathrm{ml} / \mathrm{Kg}$ dan $20 \mathrm{ml} / \mathrm{Kg}$ pakan secara tidak langsung dapat menurunkan persentase BGA, populasi Oscillatoria Sp. dan off-flavours dalam daging ikan patin dibandingkan kontrol.
\end{abstract}

Keywords: akuakultur, bacillus spp, blue green algae, off-flavors, plankton.

\begin{abstract}
A problem that often occurred for the actor of catfish cultivation was an indication of smelly mud/dirt/muddy taste (off-flavors). Off-flavors were identified from chemical geosmin compound (GSM) and 2-Methyl Iso-borneol (MIB) produced by Cyanophyceae (Blue Green Algae or BGA) and actinomycetes. This soil odor compounds were soluble in water, into the body of fish through the gill and forwarded to the fatty tissue of fish, so that the fish meat was finally mud-smelly/dirt/musty. Probiotics was an attempt to reduce the compounds that caused off-flavors. The use of probiotics containing Bacillus spp. on feed could degrade organic matter through bioremediation digestive organs and environmental fish farming to minimize the accumulation of organic matter. The reduced of organic matter in waters on total organic odor, has impacted on the percentage of BGA as cause of mud-smelly in waters, especially for species Oscillatoria Sp. In this study, the researchers used Bacillus spp. to treat $10 \mathrm{ml} / \mathrm{kg}$ and $20 \mathrm{ml} / \mathrm{kg}$ of feed that can indirectly lower the percentage of BGA, Oscillatoria population Sp. and off-flavor in catfish meat as compared to controls.
\end{abstract}

Keywords: aquaculture, bacillus spp, blue green algae, off-flavors, plankton.

\section{INTRODUCTION}

The smell of mud/dirt/muddy taste that is known as off-flavor in the catfish meat is associated with the presence of geosmin (GSM) and 2-MIB that are influenced by the plentiful nutrients and waste organic materials in the water that can cause the bloom of plankton because of poor management of water quality [1]. GSM and 2-MIB are a set of tertiary alcohol resulted as enantiomers $(+)$ and (-). GSM compounds and 2-MIB are produced as secondary metabolites of various types of bacteria, such as actinomycetes, Cyanobacteria, Proteobacteria and Fungi [2].

Cyanobacteria or Cyanophyceae can produce odor compounds mud/dirt (GSM and $2-M I B)$ of the groups/types of plankton such as Oscillatoria, Lyngbya, and Schizothrix [3]. Odor compounds are released when plankton is experiencing exponential growth phase and after death [4].

Some efforts that are carried out to reduce off-flavor are difficult, because the 
causes are variety. The substitution of water or using water recirculation (RAS) is often used to reduce the GSM and 2-MIB in catfish cultivation [5], for 10-15 hours with clean water and recirculation of the salmon, but it can reduce the body weight of fish. The diet feed is still used, but it can cause fish stress and the weight of fish declines [6]. Several attempts by the use of probiotics either through feed and water aquaculture, such as the use of Bacillus spp. of some Bacillus species such as B. subtilis, B. polymyxa, B. megaterium and $\mathrm{B}$. laterosporus which can inhibit the growth of harmful bacteria, remodel organic matter into inorganic [7].

Several types of Bacillus spp. also can produce enzyme, making digestibility of feed nutrients better, improving the health of the digestive tract and producing fish immunostimulant [8]. It is expected that with a good nutrient digestibility, it will be able to reduce the impact of increased organic matter in aquatic cultivation that stimulates abundant growth of BGA. However, the use of probiotics on the prevention or reduction of off-flavors is not yet performed, so the smell indication of mud/dirt on catfish become a problem among catfish farmers that urgently needs to explore further.

Several types of Bacillus spp. also can produce enzyme, making digestibility of feed nutrients better, improving the health of the digestive tract and producing fish immunostimulant [8]. It is expected that with a good nutrient digestibility will be able to reduce the impact of increased organic matter in aquatic cultivation that stimulates abundant growth of BGA. However, the use of probiotics on the prevention or reduction of off-flavors is not yet performed, so the smell indication of mud/dirt on catfish become a problem among catfish farmers that urgently needs to explore further.

In this study, we use and test probiotics Mina Pro dominated by B. licheniformis and B. substilis that play a role in degrading organic compound feed (protein, starch, cellulose, hydrocarbons and order) so as to produce antibiotics, playing a role in nitrification and Denitrification as well as binding nitrogen [9]. These bacteria also serves as heterotrophic and saprophytic bacteria that is Protista that behaves unicellular and includes in the microorganisms decomposers, so that it is able to seek the role of Bacillus spp. through feed to reduce off-flavors in catfish culture by emphasizing several water parameters such as the composition of $\mathrm{BGA}$ as a producer of GSM and 2-MIB in water. In addition, Bacillus spp. is also expected to be able to stabilize water chemistry as a result of the accumulation of organic matter that spreads pollution.

\section{MATERIAL AND METHOD}

This study used a completely randomized design (CRD) as method that involved 2 treatments (probiotic dose of $10 \mathrm{ml} / \mathrm{kg}$ of fish feed, $20 \mathrm{ml} / \mathrm{kg}$ of fish feed, control) and each comprising three replications. There were 9 pools involved in this study with widely of $400 \mathrm{~m} 2, \pm 2$ meters water depth, stocking density 20 tails $/ \mathrm{m} 2$ and size of fish $400 \mathrm{~g} /$ tail. The probiotics were applied 2 times/week. These were firstly diluted with $200 \mathrm{ml}$ of fresh water per $\mathrm{kg}$ of feed as well as to mix it with probiotics spraying evenly on the feed. Furthermore, it needed to stir the feed to the probiotic component that was absorbed into the pores of feed and allowed to stand for 60 minutes in the shade in order that the feed was fermented and finally carried out a feeding.

This study was conducted over 60 days in the CV. Tirta Bumi Agung (TBA), Karangdagangan village District Bandarkedung Mulyo, Jombang, East Java province. This company was led by Ilham Subekti in cooperation with PT. Central Proteinaprima. The cultivation land consisted of \pm 4 hectares of 197 plots/fish pond and devided into walking catfish (Greek language: Clarias) and catfish (Greek language: Pengasius) pond. The test for of fish samples was conducted at the Laboratory of Animal Health Services PT. Central Proteinaprima (CP. Prima) Sidoarjo, East Java.

The tools of this study included $\mathrm{pH}$ meter, DO meter, microscopes, Haemositometer, spectrophotometers and TOM testing by titration. The sample test was carried out at the Laboratory of Animal Healt Services PT. Central Proteinaprima. The research material included catfish from the pond CV. TBA, fish feed from PT. Central 
Proteinaprima and Mina Pro probiotic species Bacillus spp. from PT. Marindolab Primary.

The checking of the daily water quality involved physical parameters $(\mathrm{pH}$ and $\mathrm{DO})$, chemical mingguanparameter (Nitrite and Total Ammonia Nitrogen or TAN, Total Organic Matter or TOM), and biological parameters (plankton and bacteria water). The collection of catfish samples was carried out through random sampling with an interval time (21 days) for organoleptic testing.

The test results of each parameter was then performed through statistical tests (data normality and homogeneity) as a condition for performing Anova. If the result obtained significant, it was then forwarded to further test (Duncan test) to know the differences of each probiotics' treatment applied to decrease the smell of mud/land/muddy taste/off-flavors in catfish cultivation.

\section{RESULTS}

\section{Water Quality}

$p H$ and Dissolved Oxygen (DO)

The average result of water quality measurement $(\mathrm{pH}$ and Dissolved Oxygen) during this study is shown in Table 1 below.

Table 1. The Average Result of the Measurement of $\mathrm{pH}$ and DO (mg/L) During the Study

\begin{tabular}{|c|c|c|c|c|c|}
\hline & & \multicolumn{4}{|c|}{ The Average Result before Treatment } \\
\hline & & \multicolumn{2}{|c|}{$\mathrm{pH}$} & \multicolumn{2}{|c|}{$\mathrm{DO}(\mathrm{mg} / \mathrm{L})$} \\
\hline & & Morning & Afternoon & Morning & Afternoon \\
\hline & & 6.9 & 7.0 & 0.20 & 0.88 \\
\hline Treatment & Week & \multicolumn{4}{|c|}{ The Average Result after Treatment } \\
\hline \multirow{8}{*}{ Control } & 1 & 7.0 & 7.1 & 0.23 & 2.77 \\
\hline & 2 & 7.0 & 7.1 & 0.22 & 2.04 \\
\hline & 3 & 7.0 & 7.1 & 0.17 & 2.83 \\
\hline & 4 & 7.1 & 7.3 & 0.34 & 2.65 \\
\hline & 5 & 7.1 & 7.2 & 0.24 & 3.62 \\
\hline & 6 & 7.1 & 7.3 & 0.24 & 2.95 \\
\hline & 7 & 7.1 & 7.3 & 0.26 & 2.67 \\
\hline & Average & $7.0 \pm 0.05^{\mathrm{a}}$ & $7.2 \pm 0.06^{\mathrm{a}}$ & $0.24 \pm 0.03^{\mathrm{a}}$ & $2.79 \pm 0.45^{\mathrm{a}}$ \\
\hline \multirow{8}{*}{$\begin{array}{l}10 \mathrm{ml} / \mathrm{kg} \text { of } \\
\text { feed }\end{array}$} & 1 & 7.0 & 7.0 & 0.27 & 2.13 \\
\hline & 2 & 7.0 & 7.2 & 0.18 & 1.65 \\
\hline & 3 & 7.1 & 7.2 & 0.15 & 2.58 \\
\hline & 4 & 7.1 & 7.3 & 0.36 & 2.75 \\
\hline & 5 & 7.0 & 7.1 & 0.65 & 3.76 \\
\hline & 6 & 7.0 & 7.3 & 0.29 & 3.08 \\
\hline & 7 & 7.1 & 7.2 & 0.24 & 1.56 \\
\hline & Average & $7.0 \pm 0.03^{\mathrm{a}}$ & $7.2 \pm 0.05^{\mathrm{a}}$ & $0.30 \pm 0.05^{\mathrm{a}}$ & $2.50 \pm 0.30^{\mathrm{a}}$ \\
\hline \multirow{8}{*}{$\begin{array}{l}20 \mathrm{ml} / \mathrm{kg} \text { of } \\
\text { feed }\end{array}$} & 1 & 7.0 & 7.0 & 0.26 & 2.44 \\
\hline & 2 & 6.9 & 7.1 & 0.22 & 2.18 \\
\hline & 3 & 7.0 & 7.1 & 0.22 & 2.41 \\
\hline & 4 & 7.0 & 7.2 & 0.24 & 2.38 \\
\hline & 5 & 7.0 & 7.2 & 0.38 & 3.33 \\
\hline & 6 & 7.1 & 7.3 & 0.46 & 3.08 \\
\hline & 7 & 7.1 & 7.3 & 0.30 & 1.73 \\
\hline & Average & $7.0 \pm 0.05^{\mathrm{a}}$ & $7.2 \pm 0.08^{\mathrm{a}}$ & $0.30 \pm 0.05^{\mathrm{a}}$ & $2.51 \pm 0.30^{\mathrm{a}}$ \\
\hline
\end{tabular}

The standard of $\mathrm{pH}$ for growth of catfish is ranging from 6 to 8.5 [10]. Meanwhile, based on the standard of water quality in Governmental Regulation No. 82 year 2001 (Class II), that the $\mathrm{pH}$ is good for freshwater fish farming activities that is ranging from 69. In this study, the $\mathrm{pH}$ is still at a natural boundary and is feasible for catfish farming activities. The fluctuation value of $\mathrm{pH}$ can be affected by a decline in water conditions that have an impact on the occurrence of disease. On the condition that $\mathrm{pH}$ is humid, bacteria will grow fast while the existence of fungus will increase in acidic $\mathrm{pH}$ [11].

The standard of Dissolved Oxygen (DO) for catfish is 3-7 mg/l [10]. The parameters of Dissolved Oxygen can be used as an indicator of water freshness [12]. Oxygen plays an 
important role in the process of oxidation and reduction of organic and inorganic materials. These oxidation and reduction processes helps to reduce pollution loads in waters naturally [13]. In this study, the checking point of Dissolved Oxygen (DO) was carried out at the outlet (bottom of the pond catfish cultivation). Dissolved Oxygen (DO) is allegedly generated and tends to be lower $(0: 17 \mathrm{mg} / \mathrm{L})$. The difference in the middle and the surface of aquaculture ponds were relatively higher $(3: 50 \mathrm{mg} / \mathrm{L})$.
The value of Dissolved Oxygen (DO) when the nitrification process goes well is $>2$ $\mathrm{mg} / \mathrm{L}$ (minimum) and the growth is $>4 \mathrm{mg} / \mathrm{L}$ (medium).

\section{Nitrite and Total Ammonia Nitrogen (TAN)}

The average result of water quality measurement (Nitrite and Total Ammonia Nitrogen or TAN) during this study is shown in Table 2.

Table 2. The Average Measurement Results of Nitrite and TAN During This Study

\begin{tabular}{|c|c|c|c|c|c|c|c|}
\hline \multirow{3}{*}{\multicolumn{2}{|c|}{$\begin{array}{c}\text { The Average Result } \\
\text { before Treatment }\end{array}$}} & \multicolumn{6}{|c|}{ The Average Result after Treatment } \\
\hline & & \multicolumn{6}{|c|}{ Treatment } \\
\hline & & \multicolumn{2}{|c|}{ Control } & \multicolumn{2}{|c|}{$10 \mathrm{ml} / \mathrm{kg}$ of feed } & \multicolumn{2}{|c|}{$20 \mathrm{ml} / \mathrm{kg}$ of feed } \\
\hline $\begin{array}{l}\text { Nitrite } \\
(\mathrm{mg} / \mathrm{L})\end{array}$ & $\begin{array}{c}\text { TAN } \\
(\mathrm{mg} / \mathrm{L})\end{array}$ & $\begin{array}{l}\text { Nitrite } \\
(\mathrm{mg} / \mathrm{L})\end{array}$ & $\begin{array}{l}\text { TAN } \\
(\mathrm{mg} / \mathrm{L})\end{array}$ & $\begin{array}{l}\text { Nitrite } \\
(\mathrm{mg} / \mathrm{L})\end{array}$ & $\begin{array}{l}\text { TAN } \\
(\mathrm{mg} / \mathrm{L})\end{array}$ & Nitrite $(\mathrm{mg} / \mathrm{L})$ & $\begin{array}{l}\text { TAN } \\
(\mathrm{mg} / \mathrm{L})\end{array}$ \\
\hline 0.31 & 4.12 & $0.45 \pm 0.20^{\mathrm{a}}$ & $4.67 \pm 1.04^{\mathrm{a}}$ & $0.15 \pm 0.06^{\mathrm{a}}$ & $3.76 \pm 0.83^{\mathrm{a}}$ & $0.31 \pm 0.11^{\mathrm{a}}$ & $3.91 \pm 0.97^{\mathrm{a}}$ \\
\hline \multicolumn{2}{|c|}{$\begin{array}{l}\text { Fluctuation or } \\
\text { Comparison of } \\
\text { Treatment and } \\
\text { Control }\end{array}$} & & & 0.30 & 0.91 & 0.14 & 0.76 \\
\hline
\end{tabular}


The results showed that the average value of Nitrite and TAN has decreased after the application of probiotics that contains Bacillus spp. compared to controls. However, the statistical test indicates that it is not significantly different between the treatment of $10 \mathrm{ml} / \mathrm{kg}$ of feed and $20 \mathrm{ml} / \mathrm{kg}$ of feed and control.

The inorganic nitrogen consists of ammonia (NH3-), ammonium (NH4 +), nitrite (NO 2), and nitrogen (N2). Biologically, the process of the metabolism result of cultivation biota can be converted into Total Ammonia Nitrogen (TAN), nitrite, and nitrate (NO3). The increase in the rate of organic material degradation can be achieved if the sediment is under the aerobic conditions. In this study, the oxygen in the water is still relatively high for the process of nitrogen reform, so that the TAN and Nitrite are quite low. Bacillus spp. in the feed can degrade organic matter through the digestive organs of bioremediation and environmental fish farming to minimize the accumulation of organic matter in the water.

\section{Plankton}

The average percentage of plankton during this study is shown in Table 3 below.

Table 3. The average result of the amount of BGA plankton during this study

\begin{tabular}{|c|c|c|c|c|}
\hline \multirow{2}{*}{ Blue Green Algae } & \multirow{2}{*}{$\begin{array}{l}\text { The Average } \\
\text { Result before } \\
\text { Treatment } \\
\left.\text { (x } 10^{4} \text { cells } / \mathrm{ml}\right)\end{array}$} & \multicolumn{3}{|c|}{ The Average Result after Treatment (x $10^{4}$ cells $/ \mathrm{ml}$ ) } \\
\hline & & Control & $10 \mathrm{ml} / \mathrm{kg}$ of feed & $20 \mathrm{ml} / \mathrm{kg}$ of feed \\
\hline Anabaena & 3 & $8 \pm 1.9^{a}$ & $8 \pm 1.7^{\mathrm{a}}$ & $6 \pm 1.3^{\mathrm{a}}$ \\
\hline Chroococcus & 5 & $18 \pm 3.0^{\mathrm{b}}$ & $9 \pm 2.0^{\mathrm{a}}$ & $9 \pm 1.7^{\mathrm{a}}$ \\
\hline Merismopedia & 73 & $85 \pm 9.0^{\mathrm{b}}$ & $50 \pm 12.0^{\mathrm{a}}$ & $98 \pm 9.7^{\mathrm{b}}$ \\
\hline Oscillatoria & 169 & $161 \pm 24.3^{\mathrm{a}}$ & $137 \pm 23.0^{\mathrm{a}}$ & $135 \pm 13.9^{a}$ \\
\hline
\end{tabular}


Based on the results of the percentage of total plankton in Figure 3, it shows that the percentage of Green Algae (GA) has increased in the application of $10 \mathrm{ml} / \mathrm{kg}$ probiotics of feed and $20 \mathrm{ml} / \mathrm{kg}$ of feed than the control. Meanwhile, the BGA percentage has decreased as compared with the control. The decrease of BGA plankton average percentage is at $10 \mathrm{ml} / \mathrm{kg}(52 \%)$ and $20 \mathrm{ml} / \mathrm{kg}$ of feed $(36 \%)$. The amount of BGA plankton is empirically lower when compared with control $(56 \%)$ and prior to treatment $(71 \%)$. Thus, the use of probiotic Bacillus spp. through the feed with the application (2 times/week for 60 days) can affect the composition of the plankton, especially the number of BGA plankton producer of GSM and 2-MIB in aquaculture water.

Plankton, from the group of Cyanophyceae (Blue Green Algae) is main cause of off-flavors of fish meat producers $G S M$ and 2-MIB [14]. In observation of the BGA, the type of Oscillatoria sp. in this study experiences a decrease in treatment when compared to control. Number of drops 10 $\mathrm{ml} / \mathrm{kg}$ of feed $\left(137 \times 10^{4}\right.$ cells $\left./ \mathrm{ml}\right)$, treatment of $20 \mathrm{ml} / \mathrm{kg}$ of feed $\left(135 \times 10^{4}\right.$ cells $\left./ \mathrm{ml}\right)$ is lower than the control after treatment $\left(161 \times 10^{4}\right.$ cells $\left./ \mathrm{ml}\right)$, and control group before treatment $\left(169 \times 10^{4}\right.$ cells $\left./ \mathrm{ml}\right)$.

Some types of plankton from Cyanophyceae or BGA has been identified positive (+) as a major producer that produces GSM and 2-MIB dominated by species Oscillatoria Sp. and Lyngbya Sp [3]. Some researchers add Schizothrix species, Anabaena, and Chroococcus as well as other types of BGA. The BGA type that has been found during the investigation is allegedly as a producer of GSM and 2-MIB. In addition to the dominance Plankton Sp Oscillatoria for research, aquaculture pond water colors also indicate off-flavors and not off-flavors in Figure 1 BGA type found during the investigation allegedly as a producer of GSM and 2-MIB. In addition to the dominance of Plankton Sp.

Oscillatoria in this study, the water color of aquaculture pond also indicates offflavors and not off-flavors in Figure 1.
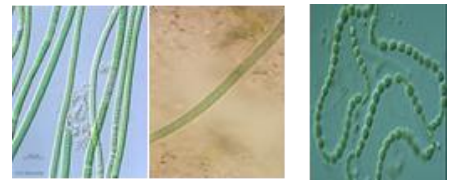

(a) Oscillatoria $S p$.

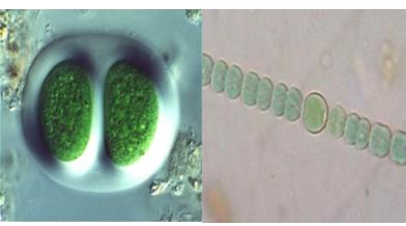

(c) Chroococcus

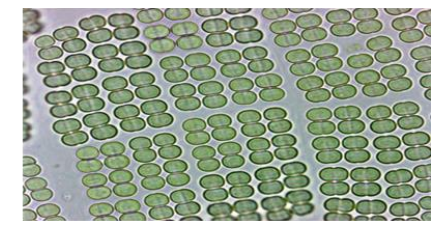

(d) Merismopedia
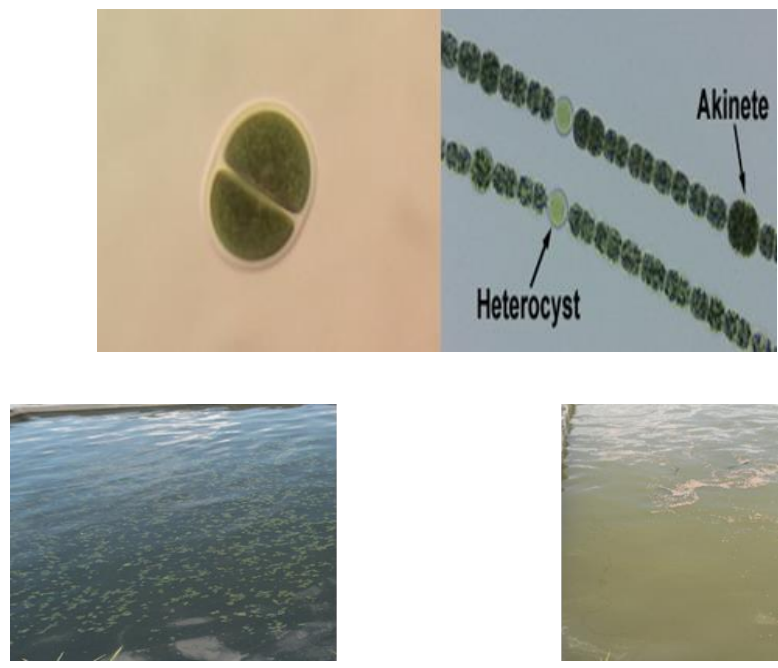

(e) Water color that indicates off-flavors

Figure 1 (a); (b); (c); (d); (e); (f). The type of BGA that is found during the investigation allegedly as a producer of GSM and 2-MIB as well as the color of aquaculture pond indicates muddy and not muddy.

Based on the results of statistical tests (ANOVA), the significance of the values organoleptic testing is >0.05 (0.866). It means that the statistical tests (ANOVA) is not significantly different in odor reduction of off-flavors land. However, from the results obtained during the study, there showed a downward trend. The observation on catfish meat (back, tail and stomach) is allegedly often found muddy smell/taste as shown in Figure 2. 


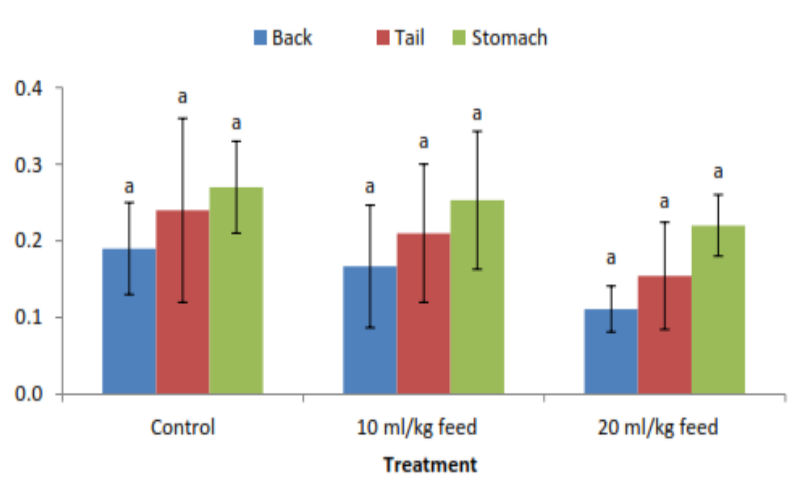

Figure 2. The average result of the catfish meat that often indicates muddy taste

\section{DISCUSSION}

Based on the average result of muddy taste test on catfish meat that indicates offflavors, it appears that the application of probiotics through the feed indicated in the treatment of $10 \mathrm{ml} / \mathrm{kg}$ of feed and $20 \mathrm{ml} / \mathrm{kg}$ of feed has decreased in part (bac, tail and stomach) is lower when compared to control. Indirectly, probiotic Bacillus spp. is able to act as decomposers bacteria through bioremediation of waters environment, so that it can compete with the microorganism $G S M$ and 2-MIB.

Organic Material of GSM and 2-MIB are semi-volatile compounds/volatile terpenoids (secondary metabolites) in the water that can be absorbed by fish and accumulate in the fatty tissue [15]. GSM and 2-MIB are chemical compounds shaped as ion/gas that are rapidly absorbed by the gills of fish. The absorption through the skin is the minor route and mostly stored in the fatty tissue [16]. In addition to the catfish, off-flavors also occurs in other fish, such as Tilapia fish (Greek language: Oreochromis Niloticus) and salmon [17].

Off-flavors has become the main reason for the problems in fish products [18]. These compounds are not toxic when concentrated in the water, but it can provide a taste and odor through waters and fish [19]. These compounds can be felt at a very low concentrations by human senses such as for $G S M 0.9 \mathrm{mg} / \mathrm{kg}$ and $0.7 \mathrm{mg} / \mathrm{kg}$ for $2-M I B$ [20]. The standard of Geosmin compound concentration for freshwater fish is 6-10 $\mathrm{mg} / \mathrm{kg}$. The speculation on the origin of offflavors in catfish meat by Leger (in 1910) is caused by Cyanobacteria. In 1960, Gerber (in 1969) and Gerber and Lechevalier (in 1965) emphasizes that the cause of off-flavors mud odor is GSM compound and 2-MIB that are isolated from cyanobacteria and actinomycetes by using chromatography gas detection.

This research was conducted as a part of efforts to improve the quality and improve the nutrition of catfish meat to meet the supply of catfish both local and non-local area. Some of the complaints by catfish farmers on the problems of smell mud smell/dirt/muddy (off-flavors) that often occur during harvest. Up to now, this case has not found any solution, although some efforts have been carried out, like using water recirculation (RAS), reducing the amount/dose of fish feed or moving the pool to another pool. However, these efforts greatly affect the growth and stress level that can cause fish mortality.

This study conducts an attempt on the application of probiotic Bacillus spp. through feed to lower off-flavors in catfish meat through suppression of BGA composition as a producer of GSM compound and 2-MIB in water and to refine chemical water (nitrite, TAN and TOM). The following is the illustration process of probiotic Bacillus spp. on feed to improve water quality (Nitrite, TAN, TOM) and to press BGA composition in waters.

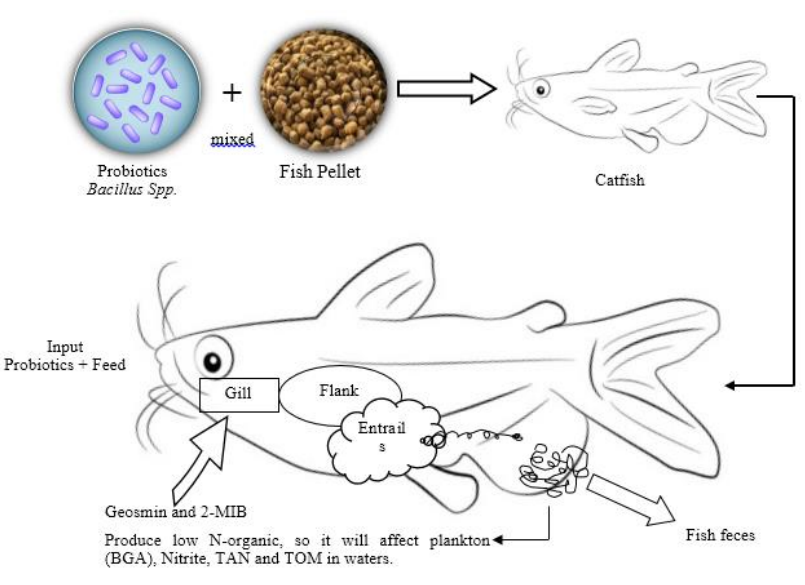

Figure 3. Illustration Probiotics work roses in the feed to improve water quality and reduce the growth of BGA 


\section{CONCLUSION}

This study has found that the use of probiotic Bacillus spp. in fish feed can lower water chemistry parameters that becomes a pollution indicator, that is nitrite value in treatment with a decrease $(0.15$ to $0.31 \mathrm{mg} / \mathrm{L})$ as compared to control $(0.45 \mathrm{mg} / \mathrm{L})$, TAN (3.76 to $3,91 \mathrm{mg} / \mathrm{L}$ ) as compared to control $(4.67 \mathrm{mg} / \mathrm{L})$, and TOM $(377-471 \mathrm{mg} / \mathrm{L})$ as compared to control $(482 \mathrm{mg} / \mathrm{L})$.

In addition, the use of probiotic Bacillus spp. in fish feed can lower the percentage of Blue Green Algae in treatment amounted to $52-36 \%$ when compared to control $56 \%$. The population of Oscillatoria $\mathrm{Sp}$. as a producer of GSM and 2-MIB has decreased the number of treatment equally to $\left(137-135 \times 10^{4}\right.$ cells $/ \mathrm{ml})$ or $\pm 15 \%$ when compared to controls $\left(161 \times 10^{4}\right.$ cells $\left./ \mathrm{ml}\right)$. Both treatments $(10 \mathrm{ml} / \mathrm{kg}$ of feed and $20 \mathrm{ml} / \mathrm{kg}$ of feed) show a decrease in the BGA typed-Oscillatoria Sp., and the treatment of $20 \mathrm{ml} / \mathrm{kg}$ of feed gives an average result lower (better).

Finally, the use of probiotic Bacillus spp. through feed can also provide water condition with lower organic level. In addition, the population of plankton as cause of off-flavors is lower. So, the result of fish organoleptic test has with the treatment of 10 $\mathrm{ml} / \mathrm{kg}$ of feed and $20 \mathrm{ml} / \mathrm{kg}$ of feed gives lower value than the control.

\section{ACKNOWLEDGEMENT}

The author would like to thank CV. Tirta Bumi Agung (TBA), Karangdagangan village District Bandarkedung Mulyo, Jombang, East Java province for readiness to be interviewed and be a subject of research. Besides, the author also would like to thank Institute for Fishery Indonesia and lecturers in Department of Fishery for any beneficial advice for this manuscript improvement and research completion. here those individual/company/institution who provided help during the research (e.g., providing language help, or proof reading the article, grant support, etc.).

\section{REFERENCES}

[1] X. Yang, X. Wu, H. I. Hao, and Z. E. He. "Mechanisms and assessment of water eutrophication," Journal of Zhejiang University Science B., vol. 9, no. 3, p. 197-209, Mar 2008.

[2] J. A. Jonns, P. R. Brooks, P. Exley, S. Poole, and D. I. Kurtboke. "Streptophage-mediated control of flavour taint producing streptomycetes isolated from barramundi ponds, "Synthetic and Systems Biotechnology., vol. 2, p. 105-112, Jun 2017.

[3] S. Chong, H. Lee, and K. G. An. "Predicting taste and odor compounds in a shallow reservoir using a three-dimensional hydrodynamic ecological model," Water., vol. 10, p. 1-19, Oct 2018.

[4] K. E. Achyuthan, J. C. Harper, R. P. Manginell, and M. W. Moorman. "Volatile metabolites emission by in vivo microalgae-an overlooked opportunity," Metabolites., vol. 7, no. 39, p. 1-46, Jul 2017.

[5] R. L. Naylor, R. W. Hardy, D. P. Bureau, P. D. Nichols, et al. "Feeding aquaculture in an era of finite resources," PNAS., vol. 106, no. 36, p. 15103-15110, Sep 2009.

[6] F. M. F. Elshaghabee, N. Rokana, R. D. Gulhane, C. Sharma, and H. Panwar. "Bacillus as potential probiotics: status, concerns, and future perspectives," Frontiers in Microbiology., vol. 8, no. 1490, p. 1-15, Aug 2017.

[7] S. H. Hoseinifar, Y. Z. Sun, A. Wang, and Z. Zhou. "Probiotics as means of diseases control in aquaculture, a review of current knowledge and future perspectives," Frontiers in Microbiology., vol. 9, no. 2429, p. 1-18, Oct 2018. 
[8] S. Cauller, C. Nannan, A. Gillis, F. Licciardi, C. Bragard, and J. Mahillon. "Overview of the antimicrobial compounds produced by members of the bacillus subtilis group," Frontiers in Microbiology., vol. 10, no. 302, p. 119, Feb 2019.

[9] M. S. Heydarnejad. "Survival and growth of common carp (cyprinus carpio L) exposed to different water $\mathrm{pH}$ levels," Turk. J. Vet. Anim. Sci., vol. 36, no. 3, p. 245-249, Aug 2012.

[10] P. Frey-Klett, P. Burlinson, A. Deveau, M. Barret, M. Tarrka, and A. Sarniguet. "Bacterial-fungal interactions: Hyphens between agricultural, clinical, environmental, and food microbiologists," Microbiology and Molecular Biology Reviews., vol. 75, no. 4, p. 583-609, Dec 2011.

[11] B. Rabha, S. Dhiman, K. Yadav, S. Hazarika, R. K. Bhola, and V. Veer. "Influence of water physicochemical characteristics on simuliidae (diptera) prevalence in some streams of Meghalaya India," J. Vector. Borne. Dis., vol. 50, no. 1, p. 18-23, Mar 2013.

[12] S. R. Pezeshki, and R. D. DeLaune. "Soil oxidation-reduction in wetlands and its impact on plant functioning," Biology., vol. 1, p. 196-221, Jul 2012.

[13] G. A. Somerville, and R. A. Proctor. "Cultivation conditions and the diffusion of oxygen into culture media: The rationale for the flask-to-medium ratio in microbiology," BMC Microbiology., vol. 13, no. 9, p. 1-2, Jan 2013.

[14] F. Moreno-Marin, J. J. Vergara, J. L. Perez-Llorenz, M. F. Pedersen, and F. G. Brun. "Interaction between ammonium toxicity and green tide development over seagrass meadows: A laboratory study," PLoS ONE., vol. 11, no. 4, p. 1-17, Apr 2016.

[15] E. Koda, A. Miszkowska, and A. Sieczka. "Levels of organic pollution indicators in groundwater at the old landfill and waste management site," Applied Science., vol. 7, no. 638, p. 122, Jun 2017.

[16] G. Vadivelan, and G. Venkateswaran. "Production and enhancement of omega-3 fatty acid from Mortierella Alpina CFR-GV15: Its food and therapeutic application," Biomed Research International., vol. 2014, no. 657414, p. 1-9, May 2014.

[17] G. S. Burr, W. R. Wolters, K. K. Schrader, and S. T. Summerfelt. "Impact of depuration of earthy-musty off-flavors on fillet quality of atlantic salmon, salmo salar, Cultured in recirculating aquaculture system," Aquacultural Engineering., vol. 50, p. 28-36, Sep 2012.

[18] K. M. I. Bashir, J. S. Kim, J. H. An, J. H. Sohn, and J. Suk Choi. "Natural food additives and preservatives for fish-paste products: A review of the past, present, and future states of research," Journal of Food Quality., vol. 9675469, p. 1-32, Nov 2017.

[19] F. Ju"ttner, and S. B. Watson. "Biochemical and ecological control of geosmin and 2-methylisoborneol in source waters," Applied and Environmental Microbiology., vol.73, no. 14, p. 4395-4406, Jul 2017.

[20] A. G. S. Gous, V. L. AImli, V. Coetzee, and H. L. de Kock. "Effects of varying the color, bitter, and sweet levels of a grapefruit-like model beverage on the sensory properties and liking of the consumer," Nutrients., vol. 11, no. 464, p. 1-16, Feb 2019.

[21] N. N. Gerber, and H. A. Lechevalier. "Geosmin: An earthy-smelling substance, isolated from actinomycetes," Appl. Microbiol., vol. 13, p. 935-938, Nov 1965. 